\title{
Hubungan Kecerdasan Logika Matematika dan Motivasi Berprestasi dengan Pemahaman Konsep Statistika pada Siswa Madrasah Aliyah Se-Kabupaten Grobogan
}

\author{
Masudi13, Muhammad Akhyar ${ }^{14}$, Akhmad Arif Musadad ${ }^{15}$ \\ Masudi1978@gmail.com
}

\begin{abstract}
This research aims to find out: (1) correlation of logical mathematic intelligence and understanding of statistic concept, (2) correlation of motivation and understanding of statistic concept, and (3) correlation of logical mathematic inteligence and motivation simultaneously with statistic concept understanding of Madrasah Aliyah students of Grobogan district in 2015/2016 academic year. This research was correlational research, which aimed to find out the correlation independent variable of logical mathematic intelligence and motivation with dependent of understanding of statistic concept. The population were all of Madrasah Aliyah students in grobogan district in 2015/2016 academic year with total of 110 students were selected as sample. They are 58 students of Madrasah Aliyah Suniyyah Selo, 32 Students of Madrasah Aliyah Nuril Huda, and 20 Students of Madrasah Aliyah Miftahut Thulab. The analysis data used simple regression and double regression analysis. Based on the results of this research, it can be concluded that: (1) logical mathematic intelligence and understanding of statistic concept of students of Madrasah Aliyah in grobogan district have a significant positive correlation, (2) motivation and understanding of statistic concept of students of Madrasah Aliyah in grobogan district have no significant positive correlation (3) Logical mathematic intelligence and motivation have a significant positive correlation simultananeously with statistic concept understanding of Madrasah Aliyah students in Grobogan district.
\end{abstract}

Keywords: Logical Mathematic Intelegence, Motivation, Statistic Concept

\footnotetext{
${ }^{13}$ Mahasiswa Magister Teknologi Pendidikan Universitas Sebelas Maret

14 Dosen Universitas Sebelas Maret Surakarta

15 Dosen Universitas Sebelas Maret Surakarta
} 


\section{PENDAHULUAN}

$\mathrm{M}$

atematika merupakan salah satu mata pelajaran yang menjadi dasar bagi ilmu pengetahuan yang lain karena di dalamnya memuat kemampuan berhitung, logika, dan berpikir. Oleh karena itu, mata pelajaran matematika perlu diajarkan di sekolah mulai dari kanak-kanak bahkan sampai ke tingkat perguruan tinggi. Jadi matematika merupakan salah satu mata pelajaran yang penting. Hal ini didukung oleh Cockroft (dalam Mulyana, 2003) yang menyatakan bahwa perlunya matematika diajarkan kepada siswa karena 1) selalu digunakan dalam segala segi kehidupan; 2) semua mata pelajaran memerlukan keterampilan matematika yang sesuai; 3) merupakan sarana komunikasi yang kuat, singkat, dan jelas; 4) dapat digunakan untuk menyajikan informasi dalam berbagai cara; 5) meningkatkan kemampuan berpikir logis, ketelitian, dan kesadaran keruangan; 6) memberikan kepuasan terhadap usaha memecahkan masalah yang menantang.

Menelaah akan penting dan peranan matematika dalam menghadapi kemajuan IPTEK dan persaingan global, maka peningkatan mutu pendidikan baik di semua jenis maupun jenjang pendidikan harus selalu diupayakan. Salah satu upaya yang dapat meningkatan mutu matematika yaitu dengan diadakannya pembelajaran matematika. Dalam pelaksanaan pembelajaran matematika tidak menutup kemungkinan akan terbentur dengan berbagai problematika. Munculnya problematika dalam pembelajaran matematika menjadi hal yang lumrah dalam mencapai tujuan tertentu. Problematika yang sering dijumpai yaitu sebagian besar siswa menganggap bahwa matematika merupakan mata pelajaran yang menakutkan dan siswa merasa bosan saat pembelajaran matematika berlangsung, sehingga sebagian besar siswa kurang menyukai matematika dan bahkan juga kurang menyukai guru matematika. Padahal siswa yang kurang suka dengan pembelajaran matematika dan guru matematika memiliki kecemasan belajar yang lebih tinggi. Hal ini didukung oleh Yuksel-Sahin (2008) dalam jurnal internasional yang mengemukakan bahwa siswa yang menyukai pembelajaran dan guru matematika memiliki kecemasan belajar yang lebih rendah. Namun pada kenyataannya sebagian besar siswa memiliki kecenderungan kecemasan belajar yang lebih tinggi sehingga berdampak pada rendah prestasi belajar matematika. Dari nilai UAN yang diperoleh dari Kemendiknas Kabupaten Grobogan menunjukkan bahwa rata-rata nilai matematika pada SMA adalah 6,55 sedangkan nilai rata-rata pada Madrasah Aliyah (MA) adalah 6,24. Dari uraian tersebut, dapat terlihat bahwa nilai matematika pada MA masih lebih rendah dari nilai matematika di SMA, maka dilakukan penelitian di MA. Berikut data nilai rata-rata UN MA Negeri dan swasta di Kabupaten Grobogan tahun pelajaran 2013/2014 dapat dilihat pada Tabel 1.1.

Tabel 1. Nilai Rata-Rata UN 2013/2014 (Kemdikbud, 2014)

\begin{tabular}{lllllll}
\hline \multirow{2}{*}{ Nilai Ujian } & \multicolumn{6}{c}{ Mata Pelajaran } \\
\cline { 2 - 7 } & B. Indonesia & B. Inggris & Matematika & Ekonomi & Sosiologi & Geografi \\
\hline Klasifikasi & C & B & C & B & B & A \\
\hline Rata-rata & 6,44 & 6,53 & 6,24 & 7,17 & 6,96 & 7,75 \\
\hline
\end{tabular}

Dari tabel di atas tampak bahwa rata-rata nilai ujian nasional mata pelajaran matematika pada jenjang Madrasah Aliyah se-Kabupaten Grobogan tahun pelajaran 2013/2014 adalah 6,24, nilai matematika ini lebih rendah daripada nilai rata-rata ujian nasional mata pelajaran Bahasa Indonesia yaitu 6,44, Bahasa Inggris yaitu 6,53, Ekonomi yaitu 7,17, Sosiologi yaitu 6,96 dan Geografi yaitu 7,75. Salah satu penyebab rendahnya nilai ujian nasional pada mata pelajaranmatematika yaitu kurangnya penguasaan materi pada indikator SKL UN. Salah satu materi yang termuat pada SKL UN 2014 pada jenjang SMA/MA yaitu statistika. Berikut data Persentase Penguasaan Materi SMA/MA Kabupaten Grobogan tahun pelajaran 2013/2014 dapat dilihat pada Tabel 2. 
Tabel 2. Persentase Penguasaan Materi Mata Pelajaran Matematika SMA/MA Kabupaten Grobogan (Kemdikbud, 2014)

\begin{tabular}{|l|l|l|}
\hline No. Urut & $\begin{array}{l}\text { Materi / kemampuan yang di } \\
\text { uji }\end{array}$ & $\begin{array}{l}\text { Nilai Rata-rata } \\
\text { Kota /Kab. }\end{array}$ \\
\hline 1 & Logika Matematika & 49,96 \\
\hline 2 & Barisan dan Deret & 64,45 \\
\hline 3 & Exponen, Barisan dan Deret & 76,37 \\
\hline 4 & $\begin{array}{l}\text { Fungsi, Persamaan dan } \\
\text { Pertidaksamaan }\end{array}$ & 67,97 \\
\hline 5 & Matriks & 70,97 \\
\hline 6 & Kalkulus & 66,95 \\
\hline 7 & Statistika dan Peluang & 53,50 \\
\hline
\end{tabular}

Pada Tabel 2 terlihat bahwa tingkat penguasaaan mengenai materi statistika pada siswa SMA/MA di Kabupaten Grobogan pada tahun 2013/2014 ini paling rendah kedua setelah Logika Matematika dibandingkan dengan penguasaan siswa pada materi yang lain yaitu hanya 53,50\%. Data ini menunjukkan bahwa masih banyak siswa SMA/MA di Kabupaten Grobogan yang mengalami kesulitan dalam memahami materi statistika sehingga menyebabkan belum optimalnya prestasi belajar siswa pada materi ini. Oleh karena itu, penelitian ini memfokuskan kajiannya pada materi statistika. Selain penguasaan materi pada materi statistika, pencapaian tinggi rendahnya prestasi belajar matematika juga dipengaruhi oleh faktor-faktor tertentu. Faktor-faktor yang mempengaruhi tinggi rendahnya prestasi belajar matematika dapat digolongkan menjadi dua faktor, yaitu faktor internal dan faktor eksternal. Faktor internal adalah faktor yang berasal dari dalam diri siswa, yaitu kecerdasan, fisiologis, sikap, minat, bakat, dan motivasi. Sedangkan faktor eksternal adalah faktor yang berasal dari luar, misalnya guru, model dan pendekatan pembelajaran, media, sarana dan prasaran.

Setiap siswa memiliki kemampuan yang berbeda-beda dalam menyelesaikan setiap masalah, tidak terkecuali masalah dalam mata pelajaran matematika. Hal yang membedakan kemampuan dalam diri siswa yaitu tingkat kecerdasan masing-masing siswa. Tingkat kecerdasan siswa dapat dikategorikan kedalam tingkat kecerdasan tinggi, sedang, ataupun rendah. Menurut penggolongannya, kecerdasan dapat dijabarkan menjadi 8 kecerdasan. Salah satu kecerdasan yang berkaitan dengan cara berpikir logis dan penalaran siswa yaitu kecerdasan logika matematika (Gardner, 2007). Kecerdasan logika matematika mencerminkan adanya kemampuan menalar siswa yang digunakan untuk menyelesaikan setiap masalah dalam pembelajaran, tidak terkecuali pada materi statistika Kelas XI Semester 1. Oleh karena itu, kecerdasan logika matematika yang baik secara tidak langsung dapat berpengaruh positif terhadap penguasaan materi statistika.

Selain itu, kecenderungan siswa untuk menghargai atau menyukai matematika (pelajaran matematika) mungkin tergantung kepada sikap siswa terhadap matematika atau pembelajaran matematika. Bagi siswa yang tidak menyenangi pelajaran matematika cenderung untuk menghindari pembicaraan mengenai pelajaran matematika, dan mungkin sebaliknya. Ketidaksenangan siswa terhadap pelajaran matematika bisa jadi dipengaruhi oleh motivasi berprestasi terhadap matematika. Seperti yang kita ketahui, motivasi berprestasi terhadap matematika berbeda-beda, ada yang memiliki motivasi berprestasi yang rendah atau tinggi, dan ada yang tidak memiliki motivasi berprestasi sama sekali (Sumardyono, 2006). Dari keterangan diatas peneliti mempunyai dugaan ada keterkaitan antara 
tinggi rendahnya kecerdasan logika matematika dan motivasi berprestasi siswa dalam pencapaian hasil belajar khususnya pemahaman konsep statistika.

Penelitian ini bertujuan untuk menemukani: (1) hubungan yang positif antara kecerdasan logika matematika dengan pemahaman konsep statistika pada siswa MA se-kabupaten grobogan. (2) hubungan yang positif antara motivasi berprestasi dengan pemahaman konsep statistika pada siswa MA sekabupaten grobogan. (3) hubungan yang positif antara kecerdasan logika matematika dan motivasi berprestasi secara simultan dengan pemahaman konsep statistika pada siswa MA se-kabupaten grobogan.

\section{METODE PENELITIAN}

Penelitian ini dilaksanakan di madrasah aliyah se-Kabupaten Grobogan Provinsi Jawa Tengah, yang secara keseluruhan terdiri dari 31 madrasah aliyah baik negeri maupun swasta. Penelitian ini merupakan peneliti-an korelasional Research. Penelitian ini digunakan untuk menemukan hubungan yang positif antara variabel bebas yaitu kecerdasan logika matematika dan motivasi berprestasi dengan variabel tak bebas yaitu pemahaman konsep statistika. Sampel dalam penelitian ini adalah 58 orang siswa dari Madrasah Suniyyah Selo sebagai wakil dari kategori bawah, 32 orang siswa dari Madrasah Nuril Huda sebagai wakil dari kategori sedang dan 20 siswa dari Madrasah Aliyah Miftahut Thulab sebagai wakil dari kategori atas. Instrumen pengumpulan data yang digunakan yaitu soal tes dan angket. Soal tes digunakan untuk pengambilan data kecerdasan logika matematika dan pemahaman konsep statistika, angket digunakan untuk pengambilan data motivasi berprestasi.

Teknik analisis data yang digunakan yaitu analisis statistik deskriptif, analisis korelasi, analisis regresi sederhana dan analisis regresi ganda. Analisis statistik deskriptif digunakan untuk menganalisis dan mendeskripsikan data yang telah terkumpul berdasarkan soal tes dan angket yang dilakukan oleh peneliti. Analisis korelasi digunakan untuk melihat sejauh mana hubungan antara variabel bebas dan variabel tak bebas, analisis regresi sederhana digunakan untuk melihat hubungan antara variabel bebas dan variabel tak bebas secara partial dengan menggunakan uji $t$, sedangkan analisis regresi ganda digunakan untuk melihat hubungan variabel bebas dan variabel tak bebas secara simultan dengan menggunakan uji F. Uji coba instrumen tes kecerdasan logika matematika, angket motivasi berprestasi dan tes pemahaman konsep statistika dilakukan di Madrsah Aliyah Negeri Purwodadi kelas XI IPA dengan responden 40 siswa. Uji coba instrumen tes kecerdasan logika matematika, angket motivasi berprestasi dan tes pemahaman konsep statistika mengacu pada kriteria yaitu validitas isi, tingkat kesulitan $(0,3 \leq T K \leq 0,70)$, daya beda $(D \geq 0,3)$, dan reliabilitas ( $\left.r_{11} \geq 0,7\right)$. Jumlah butir soal pada tes kecerdasan logika matematika dan pemahaman konsep statistika masing-masing sebanyak 30 butir soal, dan jumlah butir angket motivasi berprestasi sebanyak 16 butir angket. Hasil uji coba instrumen tes kecerdasan logika matematika dan pemahaman konsep statistikan didapatkan 25 butir soal yang digunakan, sedangkan hasil uji coba angket motivasi berprestasi didapatkan 14 butir angket yang digunakan untuk alat pengambil data.

\section{HASIL DAN PEMBAHASAN}

Data hasil penelitian sebelumnya diuji prasarat terlebih dahulu yaitu harus memenuhi kenormalan, kelinieran dan tidak terjadi multikolinieritas. Berdasarkan hasil perhitungan dengan bantuan SPSS 19 dapat ditunjukkan bahwa ketiga data baik, data kecerdasan logika matematika, data motivasi berprestasi dan data pemahaman konsep statistika semua memenuhi syarat kenormalan, kelinieran dan tidak terjadi multikolinieritas. Selanjutnya adalah uji hipotesis. (1) Hipotesis pertama yang akan diuji dalam penelitian ini berbunyi: "Terdapat hubungan positif yang signifikan antara kecerdasan logika matematika $\left(X_{1}\right)$ 
dengan pemahaman konsep statistika(Y) pada siswa Madrasah aliyah se-Kabupaten Grobogan Tahun 2015/2016. Berdasarkan hasil penelitian dapat diperoleh seperti pada tabel berikut:

Tabel 3. Rangkuman hasil analisis hubungan $X_{1}$ dengan $Y$

\begin{tabular}{llll}
\hline Korelasi & $\mathbf{r}_{\mathrm{xy}}$ & $\mathbf{t}_{\text {hitung }}$ & $\mathbf{t}_{\text {tabel }} \boldsymbol{\alpha}=\mathbf{0 , 0 5}$ \\
\hline$r_{x 1 y}$ & 0,908 & 28,105 & 1,650
\end{tabular}

Berdasarkan tabel 3, diperoleh nilai $r_{x 1 y}=0,908>0,191$ ( $r$ tabel), dan nilai thitung $=28,105>t_{\text {tabel }}$ $=1,650$, maka dapat disimpulkan bahwa hubungan linier antara variabel kecerdasan logika matematika $\left(X_{1}\right)$ dengan variabel pemahaman konsep statistika $(Y)$ sangat signifikan. Dengan demikian hipotesis yang berbunyi terdapat hubungan positif yang signifikan antara variabel kecerdasan logika matematika dengan variabel pemahaman konsep statistika terbukti kebenarannya. (2) Hipotesis kedua yang akan diuji dalam penelitian ini berbunyi: "Terdapat hubungan positif yang signifikan antara motivasi berprestasi $\left(X_{2}\right)$ dengan pemahaman konsep statistika $(Y)$ pada siswa Madrasah aliyah se-Kabupaten Grobogan Tahun 2015/2016. Berdasarkan hasil penelitian dapat diperoleh seperti pada tabel berikut:

Tabel 4.Rangkuman hasil analisis hubungan $\mathrm{X}_{2}$ dengan $\mathrm{Y}$

\begin{tabular}{llll}
\hline Korelasi & $\mathbf{r}_{\mathrm{xy}}$ & $\mathbf{t}_{\text {hitung }}$ & $\mathbf{t}_{\text {tabel }} \boldsymbol{\alpha}=\mathbf{0 , 0 5}$ \\
\hline$r_{x 2 y}$ & 0,121 & 7,203 & 1,650
\end{tabular}

Berdasarkan tabel 4, diperoleh nilai $r_{x 1 y}=0,121<0,191$ ( $r$ tabel), dan nilai thitung $=7,203>$ tabel $_{\text {tab }}$ $=1,650$, maka dapat disimpulkan bahwa hubungan linier antara variabel motivasi berprestasi $\left(X_{2}\right)$ dengan variabel pemahaman konsep statistika $(Y)$ tidak signifikan. Dengan demikian hipotesis yang berbunyi terdapat hubungan positif yang signifikan antara variabel motivasi berprestasi dengan variabel pemahaman konsep statistika tidak terbukti kebenarannya. (3). Hipotesis ketiga yang akan diuji dalam penelitian ini berbunyi: "Terdapat hubungan positif yang signifikan antara kecerdasan logika matematika $\left(X_{1}\right)$ dan motivasi berprestasi $\left(X_{2}\right)$ secara simultan dengan pemahaman konsep statistika $(Y)$ pada siswa Madrasah aliyah se-Kabupaten Grobogan Tahun 2015/2016. Berdasarkan hasil penelitian dapat diperoleh seperti pada tabel berikut :

Tabel 5. Rangkuman hasil analisis hubungan $X_{1}$ dan $X_{2}$ dengan $Y$

\begin{tabular}{llll}
\hline Korelasi & $\mathbf{r}_{x y}$ & $\boldsymbol{F}_{\text {hitung }}$ & $\boldsymbol{F}_{\text {tabel }} \boldsymbol{\alpha}=\mathbf{0 , 0 5}$ \\
\hline$r_{x 1 \times 2 y}$ & 0,939 & 395,889 & 3,07 \\
\hline
\end{tabular}

Berdasarkan tabel 5, diperoleh nilai $r_{x 1 \times 2 y}=0,939>0,191$ ( $r$ tabel), dan nilai $F_{\text {hitung }}=395,889>$ $F_{\text {tabel }}=3,07$. Maka dapat disimpulkan bahwa kecerdasan logika matematika dan motivasi berprestasi secara simultan mempunyai hubungan positif yang signifikan dengan pemahaman konsep statistika. Dengan demikian hipotesis yang berbunyi terdapat hubungan positif yang signifikan antara kecerdasan logika matematika dan motivasi berprestasi secara simultan dengan pemahaman konsep statistika terbukti kebenarannya.

Koefisien determinasi untuk mengetahui seberapa besar sumbangan semua variabel bebas dalam memprediksi variabel terikat, adalah sebesar :

$$
R_{y 1,2}^{2}=\frac{J K R}{J K T}=\frac{992,558}{1126,691}=0,881
$$


Ini berarti bahwa $88,1 \%$ nilai $Y$ dapat dijelaskan oleh persamaan regresi liniernya berdasarkan nilai $X$. Atau dengan kata lain setiap peningkatan kecerdasan logika matematika dan peningkatan motivasi berprestasi sebesar satu satuan akan diikuti peningkatan pemahaman konsep statistika sebesar $88,1 \%$. Besarnya sumbangan relatif $(S R)$ variabel kecerdasan logika matematika $\left(X_{1}\right)$ dan variabel motivasi berprestasi $\left(\mathrm{X}_{2}\right)$, masing-masing terhadap pemahaman konsep statistika $(\mathrm{Y})$ adalah sebagai berikut: (1) Sumbangan Relatif variabel $X_{1}$ terhadap $Y=74,88 \%$, (2) Sumbangan Relatif variabel $X_{2}$ terhadap $Y=25,12 \%$. Besarnya sumbangan relatif yang diberikan oleh kecerdasan logika matematika terhadap pemahaman konsep statistika pada siswa madrasah aliyah se-Kabupaten Grobogan sebesar $74,88 \%$ sedangkan sumbangan relatif motivasi berprestasi terhadap pemahaman konsep statistika adalah $25,12 \%$ sehingga total sumbangan relatif adalah $100 \%$. Sumbangan relatif tersebut menunjukkan bahwa variabel kecerdasan logika matematika mempunyai hubungan yang lebih tinggi dengan pemahaman konsep statistika pada siswa madrasah aliyah se-Kabupaten Grobogan dibanding dengan variabel motivasi berprestasi. Besarnya sumbangan efektif (SE) variabel kecerdasan logika matematika $\left(X_{1}\right)$ dan motivasi berprestasi $\left(X_{2}\right)$ masing-masing terhadap pemahaman konsep statistika $(Y)$ adalah sebagai berikut:(1) Sumbangan efektif Variabel $X_{1}$ terhadap $Y=82,90 \%$, (2) Sumbangan efektif Variabel $X_{2}$ terhadap $Y=5,20 \%$.

Sumbangan efektif yang diberikan oleh kecerdasan logika matematika terhadap pemahaman konsep statistika pada siswa madrasah aliyah se-Kabupaten Grobogan adalah $82,90 \%$ dan sumbangan efektif motivasi berprestasi terhadap pemahaman konsep statistika adalah $5,20 \%$ total sumbangan efektif yang diberikan oleh kedua variabel adalah $88,1 \%$ sedangkan sisanya sebesar $11,9 \%$ dipengaruhi oleh faktor lain diluar variabel bebas yang digunakan dalam penelitian ini antara lain : lingkungan sosial siswa, kedisiplinan siswa dan sarana prasarana yang dimiliki oleh siswa dan lain-lain. Secara berturut-turut hasil penelitian ini akan dibahas sebagai berikut:

(1) Terdapat hubungan positif yang signifikan antara kecerdasan logika matematika dan pemahaman konsep statistika pada siswa Madrasah Aliyah se-Kabupaten Grobogan. Hipotesis pertama dalam penelitian ini dapat diterima karena hasil analisis korelasi linier antara $X_{1}$ dan $Y$ diperoleh $r_{x 1 y}=$ $0,908>$ dari $r_{\text {tab }}=0,191$, sedangkan dari hasi uji keberartian diperoleh thitung $=28,105>$ dari nilai tab $=1,650$. Hal ini menunjukkan bahwa pengujian hipotesis pertama telah terbukti kebenarannya. Ini berarti semakin tinggi kecerdasan logika matematika maka akan semakin tinggi pula pemahaman konsep statistika pada siswa madrasah aliyah se-Kabupaten Grobogan. Sebaliknya semakin rendah kecerdasan logika matematika maka akan semakin rendah pula pemahaman konsep statistika pada siswa Madrasah Aliyah se-Kabupaten Grobogan, sehingga hipotesis penelitian diterima. Hal ini terbukti dengan besarnya sumbangan yang diberikan pada kecerdasan logika matematika sebesar $74,88 \%$. Dengan demikian pemahaman konsep statistika dapat ditentukan oleh tinggi rendahnya kecerdasan logika matematika yang dimiliki oleh siswa, hal ini sesuai dengan penelitian yang dilakukan oleh Kharisma Ardhy Wijayanto (2014) bahwa kecerdasan logika matematika mempunyai pengaruh yang signifikan terhadap hasil belajar siswa, dan sesuai dengan teori (Gardner, 2007) tentang kecerdasan logika matematika.

(2) Terdapat hubungan positif yang signifikan antara motivasi berprestasi dengan pemahaman konsep statistika pada siswa Madrasah Aliyah se-Kabupaten Grobogan. Hipotesis kedua dalam penelitian ini tidak dapat diterima karena hasil analisis korelasi linier antara $X_{2}$ dan $Y$ diperoleh $r_{x 2 y}=0,121$ $>$ dari $r_{\text {tab }}=0,191$, sedangkan dari hasi uji keberartian diperoleh thitung $=7,203>$ dari nilai $t_{\text {tab }}=1,650$. Ini berarti antara motivasi berprestasi dengan pemahaman konsep statistika pada siswa Madrasah Aliyah se-Kabupaten Grobogan, terdapat hubungan tetapi tidak signifikan sehingga hipotesis penelitian tidak diterima. Hal ini terbukti dengan besarnya sumbangan relatif yang diberikan pada motivasi berprestasi hanya sebesar 25,12\%. Dengan demikian pemahaman konsep statistika tidak dapat ditentukan oleh tinggi rendahnya motivasi berprestasi yang dimiliki oleh siswa Madrasah Aliyah se-Kabupaten Grobogan, hal ini tidak sesuai dengan penelitian yang dilakukan oleh Mustamin dan Sulasteri (2013) yang menyimpulkan bahwa motivasi berprestasi berpengaruh signikan terhadap hasil belajar yang dicapai oleh 
siswa sesuai dengan teorinya (McClelland, 1980) tentang motivasi berprestasi. Hal ini dimungkinkan karena motivasi berprestasi siswa itu berbeda beda, yang dipengaruhi oleh banyak faktor seperti kurangya motivasi siswa untuk memperoleh hasil yang maksimal dalam belajar, kurangnya dukungan dari keluarga untuk berprestasi, serta lingkungan belajar siswa yang tidak mendukung untuk selalu berprestasi.

(3) Terdapat hubungan positif yang signifikan antara kecerdasan logika matematika dan motivasi berprestasi secara simultan dengan pemahaman konsep statistika. Hipotesis ketiga dalam penelitian ini dapat diterima karena hasil analisis korelasi linier ganda antara $X_{1}$ dan $X_{2}$ dengan $Y$ diperoleh hitungan $r_{y 12}=0,939>r_{\text {tab }}=0,191$, sedangkan dari hasi uji keberartian menggunakan uji $F$ diperoleh $F_{\text {hitung }}=$ $395,889>$ dari nilai $F_{\text {tab }}=3,07$. Hal ini menunjukkan bahwa pengujian hipotesis ketiga telah terbukti kebenarannya. Dengan demikian hasil penelitian membuktikan bahwa terdapat hubungan yang signifikan antara kecerdasan logika matematika dan motivasi berprestasi secara simultan dengan pemahaman konsep statistika pada siswa madrasah aliyah se-Kabupaten Grobogan , sehingga hipotesis penelitian diterima.

\section{KESIMPULAN}

Berdasarkan hasil analisis data dari penelitian yang telah dilakukan terhadap siswa dengan taraf signifikan 5\%, maka dapat disimpulkan sebagai berikut:

1. Terdapat Hubungan positif yang signifikan antara kecerdasan logika matematika dengan pemahaman konsep statistika pada siswa madrasah aliyah se-Kabupaten Grobogan.

2. Tidak terdapat Hubungan positif yang signifikan antara motivasi berprestasi dengan pemahaman konsep statistika pada siswa madrasah aliyah se-Kabupaten Grobogan.

3. Terdapat Hubungan positif yang signifikan antara kecerdasan logika matematika dan motivasi berprestasi secara simultan dengan pemahaman konsep statistika pada siswa madrasah aliyah seKabupaten Grobogan.

Berdasarkan hasil dan pembahasan penelitian maka ada beberapa hal yang penulis sarankan terutama kepada siswa dan para dewan guru madrasah aliyah se-Kabupaten Grobogan.

1. Bagi siswa, Sangat diharapkan kepada seluruh siswa madrasah aliyah se-Kabupaten Grobogan, agar selalu meningkatkan kecerdasan logika matematikanya dengan belajar yang lebih giat lagi, karena dengan memiliki kecerdasn logika matematika yang tinggi akan dapat meningkatkan pemahaman konsep statistika.

2. Bagi guru, Sangat diharapkan kepada para dewan guru madrsah aliyah se-Kabupaten Grobogan, agar dapat memotivasi siswanya untuk selalu belajar dan berprestasi yang lebih baik dan maksimal, karena dengan belajar dan termotivasi dapat meningkatkan kecerdasan logika matematika dan motivasi berprestasi siswa sehingga dapat meningkat pula kemampuan siswa dalam pemahaman konsep statistika.

Bagi peneliti lain, Sumbangan efektif yang diberikan oleh kecerdasan logika matematika terhadap pemahaman konsep statistika adalah $82,90 \%$ dan sumbangan efektif motivasi berprestasi terhadap pemahaman konsep statistika adalah 5,20\% total sumbangan efektif yang diberikan oleh kedua variabel adalah $88,1 \%$ sedangkan sisanya sebesar $11,9 \%$ di pengaruhi oleh faktor lain. Oleh karena itu diharapkan kepada peneliti lain agar meneliti variabel lain yang berhubungan dengan pemahaman konsep statistika, misal lingkungan sosial siswa, sarana prasarana yang dimiliki siswa dan disiplin belajar siswa. 


\section{DAFTAR PUSTAKA}

Gardner, H. (2007). Buku Kerja Multiple Intelligences: pengalaman New City School di St. Louis, Missouri, AS, dalam menghargai aneka kecerdasan anak. Terjemahan Ary Nilandari. Bandung: Kaifa.

Kemdikbud. (2014). Laporan Ujian Nasional SMA/MA Tahun Pelajaran 2013-2014

McClelland, D. C. (1980) ."Motivations disposition: The Meriths of operant and respondent, measures", dalam L Wheeler (Ed), Review of personality and social psychology, Beverly Hills. CA: Stage

Mulyana. (2003). Pendidikan Bagi Anak Berkesulitan Belajar. Jakarta: Rineka Cipta.

Mustamin, S. H., \& Sulasteri, S. (2013). Faktor-Faktor yang Mempengaruhi Prestasi Belajar Mahasiswa Jurusan Pendidikan Matematika Fakultas Tarbiyah dan Keguruan UIN Alauddin Makassar. Jurnal Matematika dan Pembelajaran, 1(1), 151-177

Sumardyono. (2006). Pengaruh Komunikasi Matematika Terhadap Kemampuan Memecahkan Masalah (Problem Posing ) Matematika pada Siswa SMA ditinjau dari Persepsi Matematika dan Jenis Kelamin. Tesis. Universitas Sebelas Maret.

Yuksel-Sahin, F. (2008). Mathematics Anxiety Among $4^{\text {th }}$ and $5^{\text {th }}$ Grade Turkish, Elementary School Students. International Electronic Journal of Mathematics Education, 3(3), 179-192. 